\title{
ПСИХОЛОГО-ПЕДАГОГІЧНІ ЧИННИКИ РОЗВИТКУ СУБ'ЄКТНОЇ ПОЗИЦІї МАЙБУТНЬОГО ФАХІВЦЯ
}

УДК: 159.923.072.42:612.821:614.8.026.1:614.876

\section{Вовк Валентина Олегівна \\ Аспірант кафедри педагогічної та вікової психоло- гії ДВНЗ «Прикарпатський національний універси- тет імені Василя Стефраника», м. Тернопіль (Україна)}

\begin{abstract}
Анотація. Стаття присвячена дослідженню феномену суб' єктної позиції майбутнього фахівия. Актуалізована проблема розвитку суб'єктної позиції особистості студента в процесі учбово-професійної діяльності. Розглянуто та уточнено зміст означеного поняття. Виокремлено та теоретично обтрунтовано психолого-педагогічні чинники розвитку суб'єктної позиції студента.
\end{abstract}

Ключові слова: суб'єктна позиція майбутнього фахівия, суб'єкт-суб'єктна взаємодія, освітній діалог, рефлексивний аналіз.

\section{Постановка проблеми. Упродовж} останніх років процес отримання вищої освіти трансформувався у набуття важливих професійних і життєвих компетенцій та у засіб особистісної та професійної самоактуалізації майбутнього фахівця. Визначивши європейський напрямок розвитку освіти як основний і принциповий, наша країна модернізує національну систему освіти з метою гуманізації, доступності, якісності та конкурентоспроможності на тлі найкращих європейських і світових здобутків у сфері педагогічно-виховних методів та технологій.

В контексті соціально-економічних перетворень, які відбуваються сьогодні у нашому суспільстві, пріоритетним став принцип орієнтації на суб’єктний підхід до навчання, мета якого - це створення максимально сприятливих умов для саморозвитку і становлення особистості студента, виявлення та активного використання його індивідуальних особливостей та організація педагогічної взаємодії, в якій майбутній фахівець був би включений суб'єктно, тобто займав суб'єктну позицію.

\section{Аналіз останніх досліджень і}

публікацій. У науці склалися певні теоретичні передумови вирішення проблеми суб'єктної позиції майбутнього фахівця, зокрема уявлення гуманістичної психології про пріоритетний характер в розвитку людини іiі індивідуальних суб'єктних властивостей (А. Маслоу, К. Роджерс, В. Франкл, Г. Олпорт та ін.), фундаментальні праці, присвячені вивченню розвитку особистості і суб'єкта діяльності 
(К. О. Абульханова-Славська, Б. Г. Ананьєв, Л. I. Анциферова, В. А. Петровский, О. М. Леонтьєв, В. Н. Мясищев, С. Л. Рубінштейн та ін.).

Важливу роль у формуванні узагальненої концепції і моделі дослідження зіграли праці, в яких розкривається сутність феномену суб'єктності (3. М. Адамська, О. М. Волкова, 3. С. Карпенко, О. О. Конопкін, В. I. Слободчиков, В. О. Татенко, Т. М. Титаренко, Г. К. Радчук, Н. В. Чепелєва та ін.), теорії розвитку суб'єктності в системі вищої освіти (І. Д. Бех, М. Й. Боришевський, І. С. Булах, Ж. П. Вірна, О. О. Деркач, Л. В. Долинська, 3. С. Карпенко, С. Д. Максименко, В. М. Мицько, Л. М. Мітіна, В. П. Москалець, Н. А. Побірченко, Н. І. Пов'якель, Г. К. Радчук, В. В. Рибалка, М. В. Савчин, Ю. М. Швалб, Т. С. Яценко та ін.); дослідження компонентів суб'єктного досвіду (А. К. Осницький), атрибутивних характеристик суб'єктності (А. В. Петровський).

Мета статті полягає у виокремленні та обгрунтуванні психолого-педагогічних чинників розвитку суб'єктної позиції у студентському віці.

Виклад основного матеріалу дослідження. Професійно-особистісне становлення i самоактуалізація людини у студентському віці, можуть бути описані у вигляді тривалого процесу розвитку ставлень людини до своєї майбутньої професії і до самого себе як до по- тенційного суб'єкта професійної діяльності або професіонала. Г. І. Аксьонова, 3. М. Адамська, Г. К. Радчук, вивчаючи студентський вік, зазначають, що ставлення студентів до учбово-професійної діяльності багато в чому визначається розвитком у них суб'єктної позиції $[1 ; 2 ; 5]$.

Так, Г. І. Аксьонова розуміє суб'єктну позицію як складну інтегративну характеристику особистості, що відображає активновибіркове, ініціативно-відповідальне, перетворювальне ставлення до самого себе, до діяльності, світу та життя в цілому. Вона включає в себе спрямованість особистості на професію та ii цінності, прагнення до особистісної та професійної самореалізації, виражає специфічні особливості взаємодії між суб'єктами в системі освіти та $є$ показником уміння організовувати, оцінювати і здійснювати корекцію власної життєдіяльності [2].

На нашу думку, суб'єктна позиція майбутнього фахівця - це інтегративний багатокомпонентний психологічний феномен, який визначається системою особистіснозначущих, ціннісно-смислових ставлень до процесу навчання, до обраної професії, до себе як до фахівця і до свого майбутнього професійного шляху, спрямованих на саморозвиток та самоактуалізацію. Вона відображає авторство, цілісність, індивідуальність, самостійність, унікальність, здатність до рефлексії, свободи вибору та вчинкової активності.

Становлення суб'єктної позиції май- 
бутнього фахівця є тривалим, послідовним, систематичним та складним процесом, що виявляється у процесі розширення ставлень до світу, до себе та інших і припускає перехід від центрованої на самому собі до ціннісно-конструктивного освоєння і перетворення себе і всього спектру власної життєдіяльності. IIÏ актуалізація стає можливою завдяки врахуванню певних чинників, створенню соціально-психологічних умов, застосуванню в навчально-виховному процесі форм, методів, засобів, послідовна реалізація яких забезпечує гарантований результат - розвиток суб'єктної позиції студента.

Відтак, виходячи 3 даних, отриманих у теоретичному й емпіричному дослідженнях, нами визначено та обгрунтовано психологопедагогічні чинники, які сприяють розвитку суб'єктної позиції студентів в період навчання у вищій школі. Дамо їм коротку характеристику.

1. Актуалізація суб 'єкт-суб' єктної взаємодії за допомогою освітнього діалогу. Суб'єкт-суб'єктний характер стосунків на різних рівнях: викладач $\leftrightarrow$ викладач, викладач $\leftrightarrow$ студент, викладач $\leftrightarrow$ група, студент $\leftrightarrow$ студент, група $\leftrightarrow$ студент, група $\leftrightarrow$ група передбачають моделювання такого культурноосвітнього середовища (педагогічної ситуації), за якого освітній простір стає траєкторією потенційного саморозвитку студента як активновключеного суб'єкта у педагогічну взаємодію, простором набуття і творчого використання ним досвіду діяльності, трансформації і збагачення його особистості. Суб'єкт-суб'єктна взаємодія реалізує базову потребу особистості в залученні іï до соціуму і культури суспільства на основі рівноправного партнерства, хара-

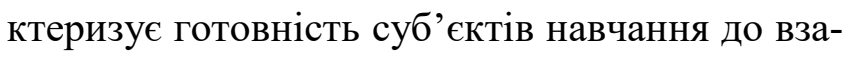
єморозуміння і взаємоповаги у процесі спілкування і діяльності, стає запорукою збереження індивідуальності, унікальності, різнорівневості й різноплановості у здібностях, можливостях, інтересах, потребах особистості.

Активізувати суб'єкт-суб'єктну взаємодію між учасниками навчального процесу, ми пропонуємо через освітній діалог як форму активного навчання, котра виступає зовнішньою спонукою внутрішнього ініціювання особистісно-професійного становлення майбутнього фахівця. Діалогічна форма навчання $є$ підгрунтям для побудови міжособистісного контакту, відкритості, довіри, співпереживання, забезпечення евристичності і проблемності навчання, критичності мислення, розвитку творчого потенціалу та продуктивної діяльності усіх суб'єктів освітнього середовища. Вона передбачає перетворення дії із самодостатньої, монологічно замкнутої на рівні професійного покладання цілей і зовнішньої стосовно навчальної дії студента у спільну зі студентом пізнавальну діяльність, де взаємоосмислено, на ціннісно-смисловому рівні будується спільний зміст освітньої діяльності.

Як зауважує Г. К. Радчук, повноцінний освітній діалог залежить від трьох складових: 
- діалогічності викладача;

- діалогічності навчального матеріалу (як фрагменту змісту освіти, що розглядається);

- $\quad$ діалогічності студента [5].

Діалогічність викладача передбачає його особистісну та професійну готовність до організації освітнього діалогу у процесі вищої професійної освіти. Особистісні властивості, стильові характеристики діяльності та спілкування, гуманістична спрямованість його особистості, розвинена потреба в самопізнанні, самоаналізі та самоактуалізації визначає здатність до викладача до ведення діалогу та співпраці із студентами.

Діалогізація освітнього матеріалу актуалізує смислове переживання та смисловопошукову активність суб'єктів освіти. Основними характеристиками конструювання таких освітніх ситуацій виступають:

- контекстуальність як здатність викладача враховувати життєву ситуацію студентів, їх потреби та актуальні переживання;

- відкритість як спосіб представлення в освітньому матеріалі відкритих для доповнення, нестійких, неоднозначних, парадоксальних фактів;

- смислотворчі інтенції педагогічного мовлення: висловлювання як відповідь і як запитання (реципрокність мовлення);

- метафоричність предметного змісту матеріалу як засіб актуалізації здатності до синкретичного інтуїтивного схоплення цілісності його структури (в єдності асоціативних, дискурсивних, логічних зв'язків);

- ігрові форми навчальної взаємодії з притаманною для гри свободою, імпровізаційністю, що дозволяє студенту розкрити професійно важливі якості, презентувати автентичний життєвий світ у спосіб експериментування з можливими суб'єктними позиціями $з$ відповідним ціннісним змістом [5].

Розвиток діалогічності студента варто розуміти як рух від уміння слухати та розуміти інші точки зору, до уміння вступати в діалог, відстоювати свою точку зору, i, що дуже важливо, навчитися сумніватися в своїй точці зору та бути відкритим для безлічі поглядів інших людей.

Таким чином, освітній діалог як інноваційна розвивальна форма навчання, в основі якої лежить особистісна готовність та професійна здатність викладача до освітнього діалогу, становлення діалогічної культури студентів та діалогізація освітнього матеріалу, актуалізує суб'єкт-суб'єктну взаємодію учасників навчального процесу, створюючи умови для самоактуалізації та розвитку суб'єктної позиції майбутнього фахівця.

2. Сприяння набуттю суб'єктного досвіду в прочесі учбово-професійної діяльності студентів. В умовах діалогічної взаємодії суб'єктів освіти особливої інтенсифікації набу- 
ває осмислене засвоєння знань як набуття суб'єктного досвіду майбутніми фахівцями (О. Г. Балл, I. Д. Бех, М. В. Кларин, С. В. Кульневич, П. В. Лушин, В. В. Сериков, Ю. В. Сенько, І. С. Якиманська та ін.). Так, основою формування суб'єктного досвіду, за I. C. Якиманською, є досвід пережитої поведінки, через який людина може оцінити свої можливості, визначити вектор напрямку своїх дій і ставлення до них, виявити значущі для себе цінності, вибудувати власну ієрархію потреб [8].

Збагачення суб'єктного досвіду майбутнього фахівця відбувається за рахунок примноження, збільшення, прирощення самостійно набутого досвіду в процесі його життєдіяльності в соціумі на основі його активності, особистісних якостей і здібностей. У процесі збагачення особистість розкриває свої внутрішні ресурси, діяльнісні здібності, можливості виконання різних соціальних ролей, зокрема i професійних. «Учіння не є безпристрасне пізнання. Це суб'єктно-значуще осягнення світу, наповненого для учня особистісними смислами, цінностями, ставленнями, зафіксованими у його суб'єктному досвіді» [8, с.24-25].

Важливими умовами, що забезпечують набуття суб'єктного досвіду особистістю, згідно з К. Роджерсом, є:

- $\quad$ наповненість змісту навчання проблемами, життєво-важливими для учнів, прагнення вирішити які спонукає їх пізнати щось нове або змінити щось у себе; конгруентність особистості педагога здатність вести себе відповідно до своїх почуттів та думок, проявляти своє істинне Я, бути таким, яким він $\epsilon$, що знімає стан напруги та психологічного захисту учнів, дозволяє йому бути самим собою $\mathrm{i}$ повністю реалізувати свої можливості;

- $\quad$ прийняття і розуміння учня, безумовно позитивне ставлення до нього, що веде до створення безпечного психологічного клімату;

- надання можливості вірного вибору i допомогу у виборі навчального матеріалу, засобів діяльності, ціннісних уподобань;

- $\quad$ опора на самоактуалізацію особистості, спонукання до виявлення у процесі навчання iї внутрішнього потенціалу до особистісного зростання [6].

Суб'єктний досвід відзначається своєрідністю, оскільки не може задаватися за допомогою традиційних програмно-методичних засобів, а лише у формі міжсуб'єктної взаємодії. Склад і структура цього досвіду не продиктовані повністю вивченим навчальним матеріалом, а обумовлені внутрішніми колізіями особистісного розвитку суб'єктів навчального процесу. Оволодіння цим досвідом проявляється не у предметних знаннях і вміннях, а у формі особистісних світоглядних диспозицій, ціннісних орієнтацій вистражданого особистісного життєвого змісту. Таке поєднання навчального процесу з рефлексивними внутріш- 
німи пошуками особистості, що розвивається, викликає і відповідне прийняття студентом «проблем викладача», тобто змісту матеріалу $\mathrm{i}$ тих вимог, які об'єктивно випливають із суті навчальної діяльності.

\section{3. Підвищення саморегулящії $і$ самокон-} тролю. Важливим чинником розвитку суб'єктної позиції студента, ми вважаємо розвиток належного рівня саморегуляції та самоконтролю. Наша думка кореспондується 3 поглядами таких науковців, як І. Д. Бех , С. Б. Кузікова, Ю. А. Миславський, про те, що саморегуляція особистості, мобілізуючи усі психологічні ресурси, сприяє управлінню їі самотворчими діями, припускає можливість людини усвідомлювати і контролювати ситуацію, процес. У розвиненій саморегуляції важливо виокремлювати уміння, що забезпечують позитивне перетворення ставлення студента до самого себе, до діяльності і спілкування, до навколишнього світу в цілому. Тобто мова йде про уміння контролювати і коригувати власну поведінку; уміння проявляти волю у досягненні мети; уміння вибирати ефективні засоби поведінки і взаємодії з оточуючими людьми.

На нашу думку, підвищенню саморегуляції та самоконтролю сприяють: розвиток у студентів усвідомлення необхідності контролю і регуляції власної поведінки; накопичення інформації про певні прийоми і способи саморегуляції та самоконтролю, володіння ними.

4. Гармонізація самоставлення і самооцุiнки. У контексті нашого дослідження одним із чинників розвитку суб'єктної позиції майбутнього фахівця є приведення у відповідність самоставлення як специфічного емоційного переживання «за» чи «проти» самого себе, яке формується на основі самосприйняття, образу Я та самооцінки як суб'єктивного утворення, що відображає оцінку особистістю своїх якостей, себе, власної успішності, а також оцінки інших людей, що формується на основі системи іï цінностей [4].

Самоставлення, яке проявляється у формі самоповаги, самоінтересу, аутосимпатії, очікувального ставлення з боку інших пов'язане 3 самооцінкою, проте ці поняття відрізняються емоційним забарвленням та змістовим наповненням. Відтак розуміння людиною сукупності наявних у неї уявлень про неї саму, оцінкових характеристик, переживань, пов'язаних 3 ними, впливають не тільки на їі сьогодення та взаємостосунки з іншими, але й на побудову «проекту майбутніх самозвершень» [7, с. 139].

Самооцінка ж пов'язана 3 потребою особистості в самоствердженні, у пошуку свого місця в житті, утвердженні себе як члена суспільства. Неадекватна самооцінка часто стає причиною порушення процесів саморегуляції, самоконтролю, призводить до міжособистісних і внутрішньо-особистісних конфліктів, зневажливого ставлення до інших людей, егоїзму тощо,

Відтак, позитивне ставлення до себе, прийняття себе як унікальної індивідуальності з усіма позитивними та негативними сторона- 
ми, недоліками та адекватна самооцінка - це ті чинники, які забезпечуватимуть гармонійне існування особистості, іï високий рівень самоідентифікації, активну роль у формуванні позитивної Я-концепції, ефективність майбутньої професійної діяльності людини і подальший розвиток iii особистості.

5. Розвиток рефлексивних умінь. Одним 3 пріоритетних чинників, що сприяє актуалізації суб’єктної позиції майбутнього фахівця, $€$ здійснення ними глибокої рефлексії, тобто детального самопізнання наявних індивідуально-психологічних особливостей своєї особистості й самосвідомості. Як влучно зазначила Г. П. Какарова, у процесі рефлексії особистість виявляе внутрішні протиріччя, що виникають між іiі цілями, завданнями і реальними можливостями їх досягнення; між переконаннями, установками, стереотипами та тенденціями до самозміни; між старим і новим у іiі житті [3]. На нашу думку, перераховані дослідницею здобутки процесу особистісного самопізнання становлять основу для розвитку суб'єктної позиції, адже одним із головних результатів рефлексії $\epsilon$ відкриття особливостей власної особистості, котрі як сприяють, так і заважають ефективній життєдіяльності й потребують вдосконалення, а набуті уміння самоспостереження, саморозкриття й самоаналізу стануть у нагоді під час реалізації майбутньої професійної діяльності та особистісній самоактуалізації .

Погоджуючись із 3. М. Адамською та Г. К. Радчук, здійснити оцінку набутих теоре- тичних знань, практичних вмінь та навичок, переконатись у правильності власного професійного вибору студенти можуть у спосіб рефлексивного аналізу професійної діяльності в процесі практики. Практика є органічною частиною навчально-виховного процесу, яка забезпечує поєднання теоретичної підготовки 3 практичною діяльністю. Саме на практиці майбутній фахівець має можливість випробувати свої сили як професіонали, застосовувати набуті знання та вміння безпосередньо в професійній діяльності. У такій роботі він виявляє свої сильні та слабкі сторони, що стимулює до постановки конкретних завдань 3 питань професійного самовдосконалення, визначення програми власного саморозвитку $[1 ; 5]$.

Отже, рефлексія дає змогу майбутньому фахівцю дати об'єктивну оцінку собі та своїм вчинкам, зрозуміти, як сприймають інші. Здатність до рефлексії - важливий аспект самосвідомості, що заохочує прагнення до саморозвитку, до вироблення власного стилю діяльності, до оволодіння необхідними навичками.

Таким чином, професійно-особистісне становлення особистості майбутнього фахівця як цілісний та динамічний процес, який розгортається в просторі і часі освітнього середовища вищої школи, передбачає розширення системи особистісно-значущих, ціннісно-смислових ставлень до самого себе, до учбово-професійної діяльності та життя в ціло- 
му. Визначальними психолого-педагогічними чинниками розвитку суб'єктної позиції майбутнього фахівця виступають: актуалізація суб'єкт-суб’єктної взаємодії за допомогою освітнього діалогу; сприяння набуттю суб'єктного досвіду в процесі учбово-професійної діяльності студентів; гармонізація самоставлення та самооцінки; підвищення саморегуляції та самоконтролю; розвиток рефлексивних умінь.

\section{Перелік використаних джерел:}

1. Адамська 3. М. Психолого-педагогічні засади розвитку суб'єктності майбутніх: дис. ... канд. психол. наук : 19.00.07 / Адамська Зоряна Михайлівна; Прикарпат. нац. ун-т ім. В. Стефаника. - Івано-Франківськ, 2010. 222 c.

2. Аксенова Г. И. Формирование субъектной позиции учителя в процессе про-фессиональной подготовки: дис. ... д-ра пед. паук: 13.00.01, 19.00.07 / Моск. пед. гос. ун-т М., 1998. - 411 с.

3. Какарова А. П. Активизация саморазвития личности учащегося средствами психолого-педагогического сопровождения / А.П. Какарова // Вестник Научной школы педагогов «АКМЕ» [под ред. М.И. Лукьяновой]. - Ульяновск: УИПКПРО, 2009. - 80 с. - С. 39-49.

4. Пантилеев С. Р. Самоотношение / С. Р. Пантилеев. // Психология самосознания. Хрестоматия. - Самара: БАХPAX-M, 2000. - C. 208-242.

5. Радчук Г. К. Аксіопсихологія вищої школи: Моногр. / Галина Кіндратівна Радчук - Тернопіль: ТНПУ ім. В. Гнатюка, 2014 - 380с.

6. Роджерс Карл. Несколько важных открытий / Карл Роджерс // Гуманистическая и трансперсональная психология. Хрестоматия / [сост. К.В. Сельченюк]. - М.: Харвест, М.: АСТ, 2000. - С.6-18.

7. Титаренко T. М. Життєвий світ особистості у межах і за межами буденності / Т. М. Титаренко. - К. : Либідь,
2003. $-376 \mathrm{c}$.

8. Якиманская И. С. Личностно-ориентированое обучение в современной школе / И.С. Якиманская // Личностно-ориентированое обучение: Хрестоматия: Для студентов гуманитарных факультетов высших учебных заведений / [сост. Е.О. Иванова, И.М. Осмоловская]. М.: СГУ, 2005. - С.182-204.

\section{References (Transliteration):}

1. Adamska Z. M. Psykholoho-pedahohichni zasady rozvytku sub'iektnosti maibutnikh: dys. ... kand. psykhol. nauk : 19.00.07 / Adamska Zoriana Mykhailivna; Prykarpat. nats. un-t im. V. Stefanyka. - Ivano-Frankivsk, 2010. $-222 \mathrm{~s}$.

2. Aksenova G. I. Formirovanie sub'ektnoj pozicii uchitelya $\mathrm{v}$ processe pro-fessional'noj podgotovki: Dis. ... d-ra ped. pauk: 13.00.01, 19.00.07 / Mosk. ped. gos. un-t M., 1998. $411 \mathrm{~s}$.

3. Kakarova A. P. Aktivizatciia samorazvitiia lichnosti uchashchegosia sredstvami psikhologo-pedagogicheskogo soprovozhdeniia / A.P. Kakarova // Vestnik Nauchnoi shkoly pedagogov «AKME» [pod red. M.I. Lukianovoi]. Ulianovsk: UIPKPRO, 2009. - 80 s. - S. 39-49.

4. Pantileev S. R. Samootnoshenie / S. R. Pantileev. // Psikhologiia samosoznaniia. Khrestomatiia. - Samara: BAKhRAKh-M, 2000. - S. 208-242.

5. Radchuk H. K. Aksiopsykholohiia vyshchoi shkoly: Monohr. / Halyna Kindrativna Radchuk - Ternopil: TNPU im. V. Hnatiuka, 2014 - 380s.

6. Rodzhers Karl. Neskolko vazhnykh otkrytii / Karl Rodzhers // Gumanisticheskaia i transpersonalnaia psikhologiia. Khrestomatiia / [sost. K.V. Selcheniuk]. - M.: Kharvest, M.: AST, 2000. - S.6-18.

7. Tytarenko T. M. Zhyttievyi svit osobystosti u mezhakh i za mezhamy budennosti / T. M. Tytarenko. - K. : Lybid, 2003. - $376 \mathrm{~s}$.

8. Iakimanskaia I. S. Lichnostno-orientirovanoe obuchenie v sovremennoi shkole / I.S. Iakimanskaia // Lichnostnoorientirovanoe obuchenie: Khrestomatiia: Dlia studentov 
gumanitarnykh fakultetov vysshikh uchebnykh zavedenii / [sost. E.O. Ivanova, I.M. Osmolovskaia]. - M.: SGU, 2005. - S.182-204.

\section{Vovk Valentina}

Postgraduate student in The Department of pedagogical and age psychology in Vasyl Stefanyk Ciscarpathian National University, Ternopol (Ukraine)

\section{PSYCHOLOGICAL AND PEDAGOGICAL FACTORS FOR THE DEVELOPMENT OF THE FUTURE SPECIALIST'S SUBJECTIVE POSITION}

\section{ABSRTACT}

The principle of orientation to the subject approach to learning became priority in the context of the social and economic transformations that take place today in our society. The purpose of which is a creation of the most favorable conditions for self-development and formation of the student's personality, identification and active use of its individual characteristics and organization of pedagogical interaction, in which the future specialist would be included subjectively.

In our opinion, the subjective position of the future specialist is an integrative multicomponent psychological phenomenon that are determined by the system of meaningful, valuable and semantic attitudes to the learning, to the chosen profession, to himself as a specialist and to the own future professional way that are aimed at self-development and self-actualization.

Based on the theoretical and empirical researches we identified and substantiated the psychological and pedagogical factors, that are contributes to the development of a student's subjective position during a period of study at a higher school. Among them:

- Actuality of the subjective interaction through the educational dialogue.

- Assistance in acquiring subjective experience in the process of educational and professional activity of students.

- Increasing self-regulation and self-control.

- Harmonization of self-assessment and selfesteem.

- Development of reflexive abilities.

Keywords: the subjective position of the future specialist, subjective interaction, educational dialogue, reflexive analysis.

\section{Вовк Валентина Олеговна}

Аспирант кафедры педагогической и возрастной психологии ГВУЗ «Прикарпатский национальный университет имени Василия Стефаника», 2. Тернополь (Украина)

\section{ПСИХОЛОГО-ПЕДАГОГИЧЕСКИЕ ФАКТОРЫ РАЗВИТИЯ СУБЪЕКТНОЙ ПОЗИЦИИ БУДУЩЕГО СПЕЦИАЛИСТА}

Аннотация. В контексте социальноэкономических преобразований, которые происходят сегодня в нашем обществе, приоритетным стал принцип ориентации на субъектный подход к обучению, цель которого - создание максимально благоприятных условий для саморазвития и становления личности студента, выявления и активного использования его индивидуальных особенностей и организация педагогического взаимодействия, в 
которой будущий специалист был бы включен субъектно, то есть занимал субъектную позицию.

По нашему мнению, субъектная позиция будущего специалиста - это интегративный многокомпонентный психологический феномен, который определяется системой личностно-значимых, ценностно-смысловых отношений к процессу обучения, к избранной профессии, к себе как к специалисту и к своему будущему профессионального пути, направленных на саморазвитие и самоактуализацию.

Исходя из данных, полученных в теоретическом и эмпирическом исследованиях, нами определены и обоснованы психологопедагогические факторы, которые способствуют развитию субъектной позиции студентов в период обучения в высшей школе:

- Актуализация субъект-субъектного взаимодействия с помощью образовательного диалога.

- Содействие приобретению субъектного опыта в процессе учебнопрофессиональной деятельности студентов.

- Повышение саморегуляции и самоконтроля.

- Гармонизация самоотношения и самооценки.

- $\quad$ Развитие рефлексивных умений.

Ключевые слова: субъектная позиция будущего специалиста, субъект-субъектное взаимодействие, образовательный диалог, рефлексивный анализ. 